Article

\title{
Flipped Learning Approach as Educational Innovation in Water Literacy
}

\author{
Antonio-José Moreno-Guerrero ${ }^{\mathbb{D}}$, José-María Romero-Rodríguez * ${ }^{\mathbb{D}}$, Jesús López-Belmonte ${ }^{\mathbb{D}}$ \\ and Santiago Alonso-García
}

Department of Didactics and School Organization, University of Granada, 18071 Granada, Spain; ajmoreno@ugr.es (A.-J.M.-G.); jesuslopez@ugr.es (J.L.-B.); salonsog@ugr.es (S.A.-G.)

* Correspondence: romejo@ugr.es; Tel.: +34-958-246-687

Received: 30 December 2019; Accepted: 18 February 2020; Published: 20 February 2020

\begin{abstract}
Water literacy has become a fundamental aspect in today's society, as its conservation, preservation and management is key to ensuring human survival. The purpose of this paper was to analyze the effectiveness of flipped learning methodology on a traditional training practice in water literacy at the first level of secondary education. The flipped learning method consisted in providing the contents to the students before the class sessions, encouraging an active learning. A descriptive study was adopted with two experimental groups, two control groups and only post-test. An ad hoc questionnaire was used as an instrument to measure the parameters: Socio-educational, Motivation, Interactions, Autonomy, Collaboration; Deepening of contents; Problem solving, Class time and Ratings. The final sample was composed of 120 students, divided into four groups of 30 students each. The application of the treatment in the experimental groups lasted 10 sessions of $55 \mathrm{~min}$. The results indicate that the use of time in class, the autonomy and the deepening of the contents were the aspects that improved most with the flipped learning approach. However, no significant differences in ratings were found. Finally, the main findings and their implications for water literacy are discussed.
\end{abstract}

Keywords: flipped learning; water literacy; water education; Likert scale; education research

\section{Introduction}

In recent times, the environment has been involved in a number of problems, which have increased alarmingly, and eliminate them or reducing their consequences is a complex undertaking to [1]. Among these problems are deforestation, climate change [2], the disappearance of species, and water scarcity and pollution, which affect our social development and our lives [3]. Currently, the most powerful tool we have to mitigate all this is Environmental Education [4]. If we specifically analyze the formation of students in relation to water, which is a necessary resource for life and social progress [5], we must propose actions that lead to reflection on the origin of this resource [6], those responsible for it and the actions that influence it, and the acquisition of skills that allow us to establish and develop solutions to this resource [7]. In this case, teaching and learning processes must also make students aware of water problems in all their dimensions [8], providing them with knowledge that allows them to understand and address the problems at the local, national and global levels [9]. Therefore, curricular elements in the area of water education should be oriented towards understanding the spatial and temporal dynamics of water [10], identifying its different uses [11], learning to conserve water [12], promoting actions that allow for better water use [13], assimilating the unequal availability of water at the global level [14], and raising awareness about the importance of natural resources that store and conserve water [15]. 


\subsection{Water Awareness and Teaching in Learning Spaces}

Awareness of water use is growing by leaps and bounds in educational systems around the world [16] due to the lack of water in certain parts of the planet [17]. The main reasons focus on drought [18], increasing pollution [19] and misuse of this natural resource [20]. Given this circumstance, Environmental Education, as an educational element, is beginning to be based on the management of water resources to make societies aware and make them active participants in actions related to environmental issues [21], oriented towards sustainable education [22]. Such is its importance that the United Nations (UN) Sustainable Development Agenda 2030 places water as Sustainable Development Goal (SDG): "SDG \#6. Clean water and sanitation" [23]. Therefore, the state of water has become a goal and a challenge to be faced in the coming years.

On the other hand, in recent years there has been widespread criticism, especially in educational policies and in the processes of teaching and learning [24], in relation to teaching on the environment, with emphasis on the preservation and care of water establishing itself as a proposal for the development of critical learning environments that make students aware of its importance [25]. The literature reveals that there is a relationship between the daily reality of household water use and the perception of its rational use [26]. In many cases, the use of didactic books that deal with the subject of water can pose substantial verbal or epistemological obstacles to adequate training [27]. For this reason, innovative educational practices are beginning to be implemented for the teaching of this content [28]. These training practices aim to make learning a pleasant and meaningful process, as well as valid for students [29]. These practices include the use of social networks [30], online learning platforms [31], gambling [32,33], problem-based learning [34], project-based learning [35], inquiry-based learning [36], or even through the use of technological tools, such as spreadsheets [37], or the use of GLOBE educational programs, which are based on environmental measurements, research and communication through ICT [38].

\subsection{Particularities of Flipped Learning in Today's Education}

Flipped learning is one of the new teaching methodologies that have emerged as a result of the constant updating of the educational field. It is understood as a teaching method of hybrid character, where the presential performance is merged with the digital one [39]. The flipped classroom is a pedagogical model that goes beyond certain pedagogical actions, such as the learning of theoretical contents, outside the classroom, and makes use of the time of the class to develop and promote, in a practical way, through questions, discussions or work dynamics, the acquisition of the contents acquired outside the classroom [40]. This method mixes direct instruction, developed in a traditional way through the expository method, with constructivist actions, which provokes a change in the roles of those involved in the teaching and learning process [41] (Table 1). This methodology is becoming popular as a teaching approach, being applied at various levels of education and achieving good results [42]. The basis of flipped learning is focused on the empowerment and optimization of the time that the student is in the classroom, in order to increase the different interactions (teacher-student, student-student, student-content), the promotion of problem solving and the possibility of deepening the contents [43]. This is based on the previous knowledge, concerns and needs of the students [44-46]. This is intended to be visualized by students before they arrive in the physical classroom [47-49]. Firstly, students anywhere and from any device with an Internet connection can access and view digital content. Later, in the classroom, this content is treated in depth and the doubts generated are resolved. This makes better use of the time spent in the classroom [50,51].

The transformation experienced by flipped learning, both in the teacher's performance (guide and counselor) and in the student's role (main protagonist), has led to the benefit of various academic indicators such as motivation [52], the attitude taken towards the completion of tasks [53], the commitment towards the achievement of objectives [54], the different interactions between agents and content $[55,56]$, the active participation of the student [57], the collaboration and socialisation between the figure of the teacher and the student and between the students $[58,59]$, the degree of 
autonomy acquired during the practice of training activities [60] and the adaptation to the educational needs of each student, encouraging individualised learning [61]. These potentialities cited have a direct and positive impact on student performance [62], closely linked to the improvement of ratings obtained $[63,64]$. This favours a higher degree of acquisition of objectives and competencies in students, as a consequence of the use of this model [65-67]. The impact literature includes research on the state of the art that certifies the effectiveness achieved by flipped learning in comparison with traditional teaching styles in which no technological resources are used [68-71].

Table 1. Comparison between expository method and flipped learning.

\begin{tabular}{|c|c|c|}
\hline Periods & Expository Method & Flipped Learning \\
\hline Before class & $\begin{array}{l}\text { The students can read something about } \\
\text { the educational contents to be dealt } \\
\text { with, while the teacher prepares the } \\
\text { theoretical presentation of the contents. }\end{array}$ & $\begin{array}{l}\text { Students visualize the explanations of } \\
\text { the contents to be worked on in class } \\
\text { previously prepared by the teacher. } \\
\text { The teacher generates and prepares } \\
\text { practical activities and class dynamics. }\end{array}$ \\
\hline During the class & $\begin{array}{l}\text { The student listens to the teacher's } \\
\text { theoretical explanation. The teacher has } \\
\text { an active attitude, while the student is } \\
\text { passive. }\end{array}$ & $\begin{array}{l}\text { The student develops dynamics and } \\
\text { practical activities during the class. } \\
\text { The teacher supervises, advises or } \\
\text { corrects the actions developed by the } \\
\text { students. The student has an active } \\
\text { attitude, while the teacher is passive. }\end{array}$ \\
\hline After class & $\begin{array}{l}\text { The students elaborate the activities that } \\
\text { have been presented in class, after the } \\
\text { theoretical explanation. The teacher } \\
\text { continues to prepare } \\
\text { theoretical presentations. }\end{array}$ & $\begin{array}{l}\text { Students reinforce what they have } \\
\text { learned in class by putting into practice } \\
\text { the activities developed and analysing } \\
\text { the theoretical videos on the contents } \\
\text { covered. The teacher continues to } \\
\text { prepare explanatory videos and work } \\
\text { dynamics to develop in class. }\end{array}$ \\
\hline
\end{tabular}

\subsection{Definition of Study Dimensions}

This research will focus on the study of various dimensions such as Socio-educational, Motivation, Interactions, Autonomy, Collaboration, Deepening of contents, Problem solving, Class time and Ratings. The choice of these dimensions is justified in the analysis of previous works reported from the impact literature where the influence caused by the application of flipped learning is studied in the aforementioned dimensions and in various contents, subjects and educational levels [68,72,73]. Therefore, to follow the path taken in previous research, we chose to analyze a dimensional set used by various experts in the field of flipped learning.

To facilitate the understanding of the results presented in this research, a definition of each of them is established:

- Socio-educational: Articulates social variables related to gender, age, city, nationality and educational variables such as the course, learning difficulties, training methodology and technological resources used.

- Motivation: Reflects the level of motivation of the students during the realization of the training actions proposed by the teacher.

- Interactions: Shows the different types of interactions that can occur in learning spaces, such as the interaction between the teacher and the students, between the students and the content of the teaching and between the students themselves.

- Autonomy: Reveals the level of autonomy achieved and the individual abilities of the students in the different activities proposed.

- Collaboration: The level of teamwork done by students in the different learning tasks. 
- Deepening of the contents: The level at which teachers work (deepens and makes a greater dedication) in the didactic content that will be taught according to the teaching and learning methodology used.

- Problem solving: Shows the student's level of ability to solve the problems raised by the teacher in the proposed training activities.

- Class time: The use of class time to work the contents programmed by the teacher and that the student must assimilate in the classroom.

- Ratings: The marks reached by the students in the different evaluation tests performed to verify the assimilation of the contents.

\section{Justification and Objectives}

The use of an innovative training approach promotes the inclusion of educational technology in learning spaces. This allows us to put into practice the new principles of education of the new millennium, giving greater prominence to the figure of the student and the use of the different technopedagogical resources that are emerging every day and whose access to the educational field cannot be denied [74]. This research is postulated as a continuity of previous works reported from the impact literature of recent years that have demonstrated the effectiveness of flipped learning in training processes $[15,17-19,45-48]$. This effectiveness is produced by contrasting flipped learning with a traditional methodology, where the teacher is the only source of information and it is transmitted in an expository way [75]. The reason why this study was placed in the Secondary Education stage is because of the familiarization with technology available to students in this age range [76]. In this way, the possible bias and typical error in experimentation is reduced, as students have to have certain skills to access, visualize and assimilate the contents digitally.

On the other hand, the general objective of the research was to analyse the effectiveness of the flipped learning methodology on a traditional training practice in the first level of Secondary Education. From this statement, the following objectives are extracted with a greater degree of concreteness: (i) to determine the degree of motivation, (ii) to determine the level of interaction (teacher-student, student-student, student-content), (iii) to find out the degree of autonomy, (iv) to discover the level of collaboration, (v) to declare the degree of deepening of the contents, (vi) to determine the level of problem solving, (vii) to find out the degree of class time, and (viii) to determine the variation of ratings.

Finally, the research questions that guided the study were:

RQ1. Does the flipped classroom method improve students' learning dimensions in water literacy?

RQ2. Are there significant differences in the different study variables between the control and experimental groups after the application of the flipped classroom method?

\section{Method}

This study was developed at a quantitative level through a descriptive and correlational approach taking into account the considerations of the experts $[77,78]$ and previous research that has followed this research process [79].

In the present study, two types of groups (control and experimental) were established to carry out relationships between study variables for a single population of students the experiment. The difference stipulated between the two groups was methodological. The control groups received training in the traditional way, without any use of technological resources. The experimental groups followed an innovative methodology through flipped learning for the teaching of the contents. In this way, the methodological approach used was configured as an independent variable and the effectiveness achieved in the different established dimensions was configured as a dependent variable. 


\subsection{Design and Participants}

A descriptive approach was adopted with 120 students in the subject of Natural Sciences in the first year of Secondary Education. According to impact studies reported in the specialized literature, for this type of research, sample size is not a determining factor for making comparisons of a single population of students $[80,81]$.

Of this group of selected students, $67.5 \%$ are boys and the rest girls with an average age of 13 years $(S D=1.42)$. These participants were grouped into four study groups as the school has four groups of students for the first level of Secondary Education. Moreover, two were of a control nature and two were of an experimental nature. Treatment allocation was established on a randomized basis. Therefore, a design with two experimental groups, two control groups and only post-test was adopted (Table 2). Although no pretest was done to check the groups' starting level, the groups were comparable. These groups had the same level, since they were first-year students in Secondary Education, where the natural groups were composed of students with the same abilities who were entering, for the first time, the educational stage of Secondary Education and specifically, the subject of Natural Sciences. Therefore, the students had no previous knowledge about the didactic unit of awareness and preservation of water as an exhaustible natural resource.

Table 2. Research design.

\begin{tabular}{cccccc}
\hline Group & $\boldsymbol{n}$ & Composition & Pretest & Treatment & Postest \\
\hline 1-Control & 30 & Natural & - & - & $\mathrm{O}_{1}$ \\
2-Experimental & 30 & Natural & - & $\mathrm{X}$ & $\mathrm{O}_{2}$ \\
3-Control & 30 & Natural & - & - & $\mathrm{O}_{3}$ \\
4-Experimental & 30 & Natural & - & $\mathrm{X}$ & $\mathrm{O}_{4}$ \\
\hline \multicolumn{7}{l}{ Note. Treatment was randomly assigned. }
\end{tabular}

The preparation of the sample was done by means of a sampling for convenience by virtue of the easy access to the different participants. This sample configuration technique was applied in an educational centre in the Autonomous City of Ceuta (Spain).

The selection of this context is justified by the cultural variety and territorial and social peculiarities of Ceuta, a border city between two countries (Spain and Morocco) and two continents (Europe and Africa) $[82,83]$. This contextualization allowed to reach a differentiating shade with respect to previous studies in which the effectiveness of a methodological contrast has been verified.

\subsection{Instrument}

An ad hoc questionnaire was designed based on previous studies $[15,46,76,84,85]$ focusing on variables that are relevant to the development of teaching methods associated with flipped learning, as observed in several previous studies on this teaching method [27-44]. This instrument consists of 35 questions catalogued in nine dimensions (Socio-educational, Motivation, Interactions, Autonomy, Collaboration; Deepening of contents; Problem solving, Class time and Ratings). The presentation of the items is clarified by a four-level Likert scale (from $1=$ None to $4=$ Completely).

For content validity, the Delphi method was used with the purpose of knowing, from a qualitative point of view, the opinion of various experts $(n=8)$. These specialists expressed a positive opinion $(M=4.64 ; S D=0.37 ; \min =1 ; \max =6)$ and offered recommendations for optimizing the instrument. These focused on unifying items in the same category to reduce the total number of questions and modifying several words to improve understanding of the items. This feedback was done, on the one hand, with the intention of not presenting an instrument with a large volume of questions that lead to saturation and frustration of the participants and, on the other hand, to adjust the lexicon to the level of the students and not to cause bias due to lack of understanding of the items. To complement this first validation, two statistical procedures were applied as Kappa by Fleiss and W by Kendall to 
obtain the degree of agreement and relevance of the judgments issued by the specialists. In these tests, appropriate values $(K=0.84 ; \mathrm{W}=0.86)$ were reached which verify the relevance of the experts' opinions.

The validation of the construct was carried out from the exploratory factorial analysis by means of the principal components method and a varimax rotation. The Bartlett's test of sphericity revealed dependence between the established variables $(2613.28 ; p<0.001)$ and the Kaiser-Meyer-Olkin test offered optimal values that certify the adequacy of the sample $(\mathrm{KMO}=0.87)$.

For the reliability of the questionnaire, several statistics were found, such as Cronbach's alpha $(\alpha)$ (0.86), Compound reliability (0.84) and Mean variance extracted (0.81). Scores that confirmed the internal consistency of the instrument applied were obtained.

\subsection{Procedure and Data Analysis}

The study carried out had different phases of research. First, the sample was selected. For this first action, the researchers met with the school in order to develop the study and access to the student sample. The school in question showed complete agreement to carry out the study, which facilitated both the sample selection phase and the training and completion of the instrument. Thus, the informed consent of the participants was obtained.

Then, a didactic unit composed of 10 sessions of 55 min each was carried out, where the different contents related to the subject of awareness and preservation of water as an exhaustible natural resource were taught. The contents were: (a) water as a vital resource; (b) responsible use of water; (c) measures to promote reasonable use of water; (d) consequences of its depletion; (e) alterations caused by climate change.

This didactic unit was developed through two different methodologies according to the study group (Control $=$ traditional method without the use of ICT; Experimental $=$ flipped learning). Specifically, the control groups focused the didactic approach on a traditional transmission of the contents through the master class. The teacher's role was to prepare audiovisual material and upload it to a content management platform so that students could view it prior to the face-to-face session. Thus, the students came to the classroom with the content they had seen. This action helped to allocate more class time to resolve doubts about the content taught digitally and to delve into other aspects of the subject. Once the unit was completed, the data collection process took place by means of the questionnaire. Finally, there was a statistical analysis that allowed the extraction of results and the subsequent establishment of conclusions in order to respond to the proposed objectives.

The statistical analysis was carried out with the Statistical Package for the Social Sciences (SPSS) v25 program (IBM Corp., Armonk, NY, USA). Basic statistics such as mean (M) and standard deviation (SD) were used. The trend in distribution has been determined by testing for skewness $\left(S_{k w}\right)$ and kurtosis $\left(K_{\mathrm{me}}\right)$. The comparative study of the means between the groups was carried out with the t-Student test $(\mathrm{tn} 1+\mathrm{n} 2-2)$. The size of the effect achieved has been extracted with Cohen's $d$ and the biserial correlation $\left(r_{x y}\right)$. The statistical treatment was deployed taking a $p<0.05$ as a statistically significant difference. In this conventional methodology, the teacher is a simple player of content transmitted in an expository way as the main relevant agent of the teaching and learning process. As for the experimental groups, a methodology based on flipped learning was followed. This contributed to certain educational potentialities that favoured access to information in a ubiquitous way, the advancement of contents before the face-to-face class and the change of roles between teachers and students, with the latter achieving an active, leading and socio-constructive perspective on knowledge.

\section{Results}

\subsection{RQ1. Does the Flipped Classroom Method Improve Students' Learning Dimensions in Water Literacy?}

In Table 3, the descriptive data were collected. The means achieved by both the control groups and the experimental groups in each of the variables studied are shown. In this case, it is reflected as the averages of the control groups did not exceed the average of 2.5. In contrast, in the experimental 
groups this average is exceeded for all variables, except for student interaction with respect to content, which is below (2.3). In addition, the values of asymmetry and kurtosis showed a normal distribution, these being between -1.96 and +1.96 [86]. The standard deviation gives more equal results in all variables, except in the scores achieved for the control groups, and in the students' autonomy and content deepening in the experimental groups, where the students' responses were more dispersed. Kurtosis is platicuric in all variables, except in the interaction between students, which is leptocuric, and in the marked relationship between students and the proposed contents, which is mesocuric.

Table 3. Results obtained for the study variables in the control groups and experimental groups.

\begin{tabular}{|c|c|c|c|c|c|c|c|c|c|}
\hline & Variables & \multicolumn{4}{|c|}{ Likert Scale $n(\%)$} & \multicolumn{4}{|c|}{ Parameters } \\
\hline \multirow{8}{*}{$\begin{array}{l}\text { Control } \\
\text { groups }\end{array}$} & Motivation & $5(16.7)$ & 11(36.7) & $12(40)$ & $2(6.7)$ & 2.37 & 0.850 & -0.093 & -0.594 \\
\hline & Teacher-student & $7(23.3)$ & $15(50)$ & $8(26.7)$ & $0(0)$ & 2.03 & 0.718 & -0.050 & -0.954 \\
\hline & Student-content & $8(26.7)$ & $19(63.3)$ & $3(10)$ & $0(0)$ & 1.83 & 0.592 & 0.040 & -0.082 \\
\hline & Student-student & $4(13.3)$ & $18(60)$ & $7(23.3)$ & $1(3.3)$ & 2.17 & 0.699 & 0.409 & 0.591 \\
\hline & Deepening & $19(63.3)$ & $11(36.7)$ & $0(0)$ & $0(0)$ & 1.37 & 0.490 & 0.583 & -1.78 \\
\hline & Resolution & $8(26.7)$ & $18(60)$ & $4(13.3)$ & $0(0)$ & 1.87 & 0.629 & 0.098 & -0.321 \\
\hline & Class time & $23(76.7)$ & $7(23.3)$ & $0(0)$ & $0(0)$ & 1.23 & 0.430 & 1.32 & -0.257 \\
\hline & Ratings $^{a}$ & $6(20)$ & $10(33.3)$ & $9(30)$ & $5(16.7)$ & 2.43 & 1.01 & 0.086 & -0.991 \\
\hline \multirow{7}{*}{$\begin{array}{l}\text { Experimental } \\
\text { groups }\end{array}$} & Motivation & $0(0)$ & $9(30)$ & $13(43.3)$ & $8(26.7)$ & 2.97 & 0.765 & 0.058 & -1.23 \\
\hline & Autonomy & $5(16.7)$ & $11(36.7)$ & $7(23.3)$ & $7(23.3)$ & 2.53 & 1.04 & 0.101 & -1.13 \\
\hline & Collaboration & $1(3.3)$ & $8(26.7)$ & $12(40)$ & $9(30)$ & 2.97 & 0.850 & -0.295 & -0.724 \\
\hline & Deepening & $5(16.7)$ & $10(33.3)$ & $8(26.7)$ & $7(23.3)$ & 2.57 & 1.04 & 0.007 & -1.12 \\
\hline & Resolution & $3(10)$ & $9(30)$ & $11(36.7)$ & $7(23.3)$ & 2.73 & 0.944 & -0.208 & -0.791 \\
\hline & Class time & $0(0)$ & $8(26.7)$ & $8(26.7)$ & $14(46.7)$ & 3.20 & 0.847 & -0.409 & -1.49 \\
\hline & Ratings $^{a}$ & $3(10)$ & 11(36.7) & 11(36.7) & $5(16.7)$ & 2.60 & 0.894 & -0.012 & -0.648 \\
\hline
\end{tabular}

Note. ${ }^{a}=$ Score achieved in the assessment test (None: 1-4.9; Few: 5-5.9; Enough: 6-8.9; Completely: 9-10).

\subsection{RQ2. Are There Significant Differences in the Different Study Variables between the Control and Experimental Groups after the Application of the Flipped Classroom Method?}

The comparison of means between the control groups and the experimental groups with respect to the variables applied in the study showed a higher mean in all the variables of the group where the flipped learning teaching method is applied with respect to the traditional method. The biggest differences are shown in the student's autonomy and the deepening of contents, where the distance is substantial. The smallest difference is in the ratings achieved by the students (Figure 1).

To establish the value of independence of the data collected between the traditional teaching method and the flipped learning method, the Student's $t$-test for independent samples was applied. The results indicate that there were significant differences in Motivation, interactions Teacher-Student and Student-Content, Autonomy, Collaboration, Deepening, Resolution and Class time, given that their $p$-value was below 0.01 , and in the relationship given between the students, where the correlation was $<0.05$. However, in the ratings reached by the students, the difference was not significant either in the $t$-value or in the biserial correlation, which shows that the flipped learning method increased the value of all the variables analyzed, except in the ratings where there was no direct incidence. The strength in the association of the variables by means of the biserial correlation, offered a greater effect in the autonomy of the students, the deepening of the contents and the use of the time during the development of the pedagogical actions, due to the fact that its values were above 0.5 . In the rest of the variables where there had been a relationship of significance, the force of association is average. If we 
consider the value offered in all the variables, the size of the effect offered by Cohen's statistician $d$ was small in all cases (Table 4).

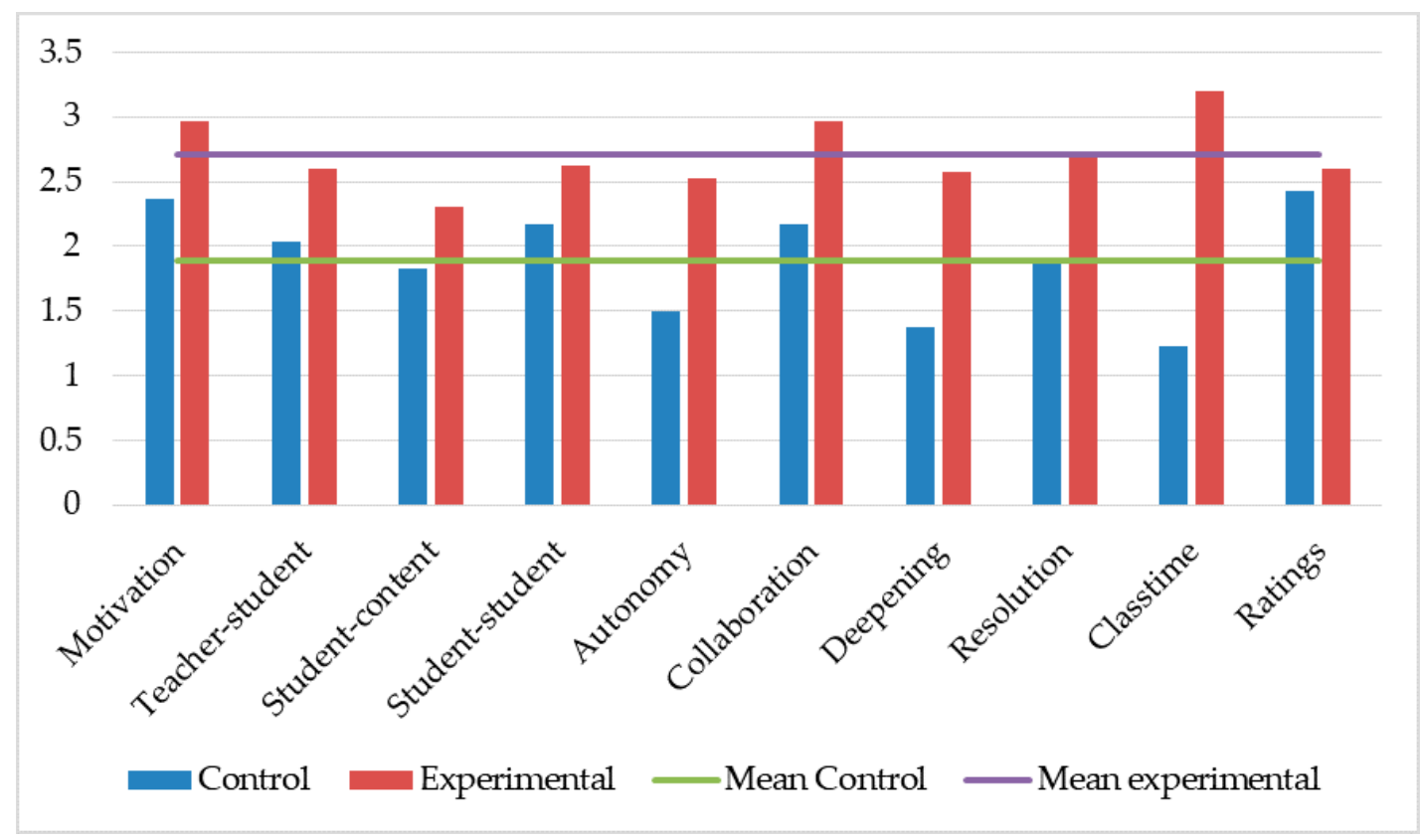

Figure 1. Comparison between control groups and experimental groups.

Table 4. Value of independence between the control groups and the experimental groups.

\begin{tabular}{lccccc}
\hline \multicolumn{1}{c}{ Variables } & $\boldsymbol{\mu}(\mathbf{X 1} \mathbf{X} \mathbf{X})$ & $\boldsymbol{t}_{\boldsymbol{n} \mathbf{1 + n \mathbf { n } - \mathbf { 2 }}}$ & $\boldsymbol{d f}$ & $\boldsymbol{d}$ & $\boldsymbol{r}_{\boldsymbol{x} y}$ \\
\hline Motivation & $-0.600(2.37-2.97)$ & $-2.873^{* * *}$ & 58 & 0.032 & 0.353 \\
Teacher-student & $-0.567(2.03-2.60)$ & $-2.859^{* *}$ & 58 & -0.023 & 0.352 \\
Student-content & $-0.467(1.83-2.30)$ & $-2.676^{* *}$ & 58 & -0.013 & 0.331 \\
Student-student & $-0.467(2.17-2.63)$ & $-2.259^{*}$ & 58 & -0.036 & 0.284 \\
Autonomy & $-1.033(1.50-2.53)$ & $-4.883^{* *}$ & 58 & 0.081 & 0.540 \\
Collaboration & $-0.800(2.17-2.97)$ & $-3.512^{* *}$ & 58 & 0.000 & 0.419 \\
Deepening & $-1.200(1.37-2.57)$ & $-5.717^{* *}$ & 58 & 0.173 & 0.600 \\
Resolution & $-0.867(1.87-2.73)$ & $-4.184^{* *}$ & 58 & -0.049 & 0.481 \\
Class time & $-1.967(1.23-3.20)$ & $-11.34^{* *}$ & 58 & 0.293 & 0.830 \\
Ratings ${ }^{\text {a }}$ & $-0.167(2.43-2.60)$ & n.s. & 58 & 0.044 & 0.089 \\
\hline
\end{tabular}

Note. ${ }^{* *}=$ The correlation is significant at the 0.01 level; ${ }^{*}=$ Correlation is significant at the 0.05 level; n.s. $=$ Not significant; $^{\mathrm{a}}=$ Score achieved in the assessment test (None: 1-4.9; Few: 5-5.9; Enough: 6-8.9; Completely: 9-10).

\section{Discussion and Conclusions}

The data collected in this study showed that all the means obtained in the nine dimensions were superior in the experimental groups. Therefore, the development of different skills, such as student motivation and engagement, was confirmed with the application of flipped learning compared to the traditional method in water education [67-69]. At the same time, data were obtained that indicated that the flipped learning approach collected that the socio-educational dimension was greater, as indicated by other authors [53,54,56,60]. There was an increase in motivation [51] and increased teacher-student, student-student and student-content interactions [46-48,54]. An increase in student autonomy was also fount $[43-45,59]$, as well as greater collaboration among students $[57,58]$. There was a deepening of content and a greater willingness to solve problems autonomously [42]. Class time was improved [48,49] and ratings were slightly higher [61-63]. 
However, the biggest differences were found in the autonomy of the students and in the deepening of the contents. Thus, with the application of flipped learning, significant learning was encouraged in the students. However, there were no significant differences in the scores, although the average was higher in the experimental groups. These findings are related to the good results that flipped learning is obtaining in other contexts [39-41].

On the other hand, the use of time in the classroom was the greatest average and main benefit, which directly affects student learning [52], due, in the first instance, to the ease of access to content from home [64]. Thus, in the case of the experimental groups, the time in the classroom was used to share the knowledge acquired individually with the whole group, to solve doubts and problems. This had a direct impact on water literacy. Likewise, the use of innovative methodologies that allow a greater understanding in the teaching of key aspects, such as water, is fundamental, since it will determine the way of life in the coming years [27,28]. At the same time, it is essential that learning be meaningful in order to generate ecological awareness in students [21].

In short, this paper analyzed the effectiveness of the flipped learning methodology on a traditional training practice in water literacy at the secondary education stage. All this was favored by the change of roles between the different educational agents. The teacher assumed a passive role, leaving all the prominence and main activity to the student, who, through the viewing of the audiovisual materials and the collaboration with other students, carried out a teaching and learning process that proved to be beneficial to solve the problems and perform the activities proposed by the teacher, in a climate of collaboration to achieve together the construction of knowledge on the subject. The main finding obtained was the evidence on the improvement of student motivation and engagement through flipped learning. These data are relevant to water literacy, with a flipped learning being an approach that produces a greater understanding of the content.

The limitations of the study include the cross-sectional nature and convenience sampling. Furthermore, this study was conducted in a specific population and there may be limitations in generalizing the results outside that population. In future studies, this design should be replicated in other contexts to compare the results obtained with those obtained in this paper.

Author Contributions: All authors have contributed equally. All authors have read and agreed to the published version of the manuscript.

Funding: Ministry of Education, Culture and Sport of the Government of Spain (Project reference: FPU16/01762).

Acknowledgments: To the researchers of the research group AREA (HUM-672). Research group by belonging to the Ministry of Education and Science of the Junta de Andalucía and based in the Department of Didactics and School Organization of the Faculty of Education Sciences of the University of Granada.

Conflicts of Interest: The authors declare no conflict of interest.

\section{References}

1. Martins, R.; Mirandola, P.H.; De Souza, M.H. Relationship between environmental fragility, surface water quality, and permanent preservation areas in San Domingos Stream, tres Lagoas-ms. Geosaberes 2020, 11, 1-20. [CrossRef]

2. Wadsworth, F.B.; Vossen, C.E.J.; Schmid, D.; Colombier, M.; Heap, M.J.; Scheu, B.; Dingwell, D.B. Determination of permeability using a classic Darcy water column. Am. J. Phys. 2020, 88, 20-24. [CrossRef]

3. Zhang, L.; Zhou, J.W.; Zhang, N.; Gong, W. Numerical investigation on the solid particle erosion in elbow with water-hydrate-solid flow. Sci. Prog. 2019, 1-25. [CrossRef] [PubMed]

4. Akerblom, A.; Souckova, D.; Pramling, N. Preschool children's conceptions of water, molecule, and chemistry before and after participating in a playfully dramatized early childhood education activity. Cult. Stud. Sci. Educ. 2019, 14, 1-17. [CrossRef]

5. Alicea-PLanas, J.; Dresel, S.; Ferrante, A.; Vasquez, W. Factors influencing carbonated soft-drink and bottled water consumption: Survey evidence from Nicaragua. Int. J. Health Promot. Educ. 2019, 1-14. [CrossRef]

6. Lobato, V.S.; Ferreira, C.L. Knowledges and professionality of the Water Pedagogy course graduates: A focus on the early training. Educ. Rev. 2019, 35, 167-185. [CrossRef] 
7. Meehan, P. Water Into Wine: Using Social Policy Courses to Make MSW Students Interested in Politics. J. Soc. Work Educ. 2019, 1-15. [CrossRef]

8. Wang, W.; Zhang, Q.D.; Tang, T.; Lu, S.P.; Yi, Q.; Wang, X.F. Numerical study of the impact of water injection holes arrangement on cavitation flow control. Sci. Prog. 2019, 1-23. [CrossRef]

9. Cole, M.H.; Rosenthal, D.P.; Sanger, M.J. Two studies comparing students' explanations of an oxidation-reduction reaction after viewing a single computer animation: The effect of varying the complexity of visual images and depicting water molecules. Chem. Educ. Res. Pract. 2019, 20, 738-759. [CrossRef]

10. Dewald, S.S.; Murphrey, T.P.; Leggette, H.R.; Berthold, A.; Wagner, K. Landowner Adoption of Water Quality Best Management Practices: Motivations and Barriers. J. Ext. 2019, 57, 1-10.

11. Torres, P.A. Educational research in Cuba: The delayed rescue of the "child thrown out with the dirty water". Atenas 2019, 4, 1-32.

12. Fernández, C.L.; Correia, I.; Assunçao, O.M. Water footprint Water -A Finite Resource to Preserve: Case Study in two class of Elementary School. REMEA Rev. Electrónica Mestr. Educ. Ambient. 2019, 36, $276-291$. [CrossRef]

13. Ahammed, F.; Smith, E. Prediction of Students' Performances Using Course Analytics Data: A Case of Water Engineering Course at the University of South Australia. Educ. Sci. 2019, 9, 245. [CrossRef]

14. Gilmore, T.E.; Korus, J.; Pennisi, L.; Martin, D.; Pekarek, K. Needs Assessment: Watershed Science for Water Resources Directors. J. Ext. 2019, 57, 1-11.

15. Muntz, H.; Koop, K. Influencing Water Consumption through the Water Check Program. J. Ext. 2019, 57, 1-6.

16. Cheng, P.H.; Yeh, T.K.; Tsai, J.C.; Lin, C.R.; Chang, C.Y. Development of an Issue-Situation-Based Board Game: A Systemic Learning Environment for Water Resource Adaptation Education. Sustainability 2019, 11, 1341. [CrossRef]

17. Amahmid, O.; El Guamri, Y.; Yazidi, M.; Razoki, B.; Rassou, K.K.; Rakibi, Y.; Kniki, G.; El Ouardi, T. Water education in school curricula: Impact on children knowledge, attitudes and behaviours towards water use. Int. Res. Geogr. Environ. Educ. 2019, 28, 178-193. [CrossRef]

18. Hoy, L.; Stelli, S. Water conservation education as a tool to empower water users to reduce water use. Water Sci. Technol. Water Supply 2016, 16, 202-207. [CrossRef]

19. Gizaw, Z.; Addisu, A.; Dagne, H. Effects of water, sanitation and hygiene (WASH) education on childhood intestinal parasitic infections in rural Dembiya, northwest Ethiopia: An uncontrolled before-and-after intervention study. Environ. Health Prev. Med. 2019, 24, 1-8. [CrossRef]

20. Santana, A.C.; Franca, D.A. Enviromental education for wáter consciousness. REMEA. REMEA Rev. Electron. Mestr. Educ. Ambient. 2012, 28, 178-188.

21. Medeiros, T.M.; Santos, J.L.; Silva, E. Water vulnerability in the Brazilian Northeast: Between urbanization and Environmental Education. REMEA Rev. Electron. Mestr. Educ. Ambient. 2018, 35, 184-199. [CrossRef]

22. Vehmaa, A.; Karvinen, M.; Kerkinen, M. Building a More Sustainable Society? A Case Study on the Role of Sustainable Development in the Education and Early Career of Water and Environmental Engineers. Sustainability 2018, 10, 2605. [CrossRef]

23. United Nations. Transforming Our World: The 2030 Agenda for Sustainable Development; United Nations: New York, NY, USA, 2015.

24. Kilkis, S.; Kilkis, B. Integrated circular economy and education model to address aspects of an energy-water-food nexus in a dairy facility and local contexts. J. Clean. Prod. 2017, 167, 1084-1098. [CrossRef]

25. Davis, N.R.; Schaeffer, J. Troubling Troubled Waters in Elementary Science Education: Politics, Ethics \& Black Children's Conceptions of Water [Justice] in the Era of Flint. Cogn. Instr. 2019, 37, 367-389. [CrossRef]

26. Souza, J.R.; Mieguins, A.M. The perception of fundamental education students on the use of consumed water in the county of Belem-PA. REMEA Rev. Electron. Mestr. Educ. Ambient. 2018, 35, 155-172. [CrossRef]

27. Quevedo, N.; Schmeider, E.M.; Della, L.A. Epistemological obstacles on Water in didactic science books of sixth grade of basic education, in the PNLD 2017 of Brazil. Gondola Enseñanza Y Aprendiz. De Las Cienc. 2019, 14, 376-391. [CrossRef]

28. Vitor, J.; Goncalvez, R.S.; Sánchez, C. The "Water Societies": Environmental Education in a Community Favela in Rio de Janeiro. Droit Cult. 2019, 78, 139-158.

29. Dos Santos, J.G.; Rodrigues, C. Environmental education in the teaching of Chemistry: "water" as a generative theme. REMEA Rev. Electron. Mestr. Emeducaçao Ambient. 2018, 35, 62-86. [CrossRef] 
30. Hove, C.; Osunkun, O.O. Social Media Use for Water Conservation Education in South Africa: Perceptions of Raymond Mhlaba Local Municipality's Residents. J. Asian Afr. Stud. 2019, 1-19. [CrossRef]

31. Wang, H.; Xu, H.; Li, Q.; Fu, Y. PHP-based collaborative education and management system for water hydraulic laboratory. Comput. Appl. Eng. Educ. 2018, 26, 259-271. [CrossRef]

32. Do Nascimiento, A. "Rain, Rain, Go Away!” Engaging Rain Pedagogies in Practices with Children: From Water Politics to Environmental Education. J. Child. Stud. 2019, 44, 42-55. [CrossRef]

33. Monteira, S.F.; Jiménez, M.P. How does water get to the clouds? Building explanations about state changes in Early Childhood Education. Rev. Eureka Sobre Enseñanza Y Divulg. De Las Cienc. 2019, 16, 1-16. [CrossRef]

34. Habib, E.; Deshotel, M.; Lai, G.L.; Miller, R. Student Perceptions of an Active Learning Module to Enhance Data and Modeling Skills in Undergraduate Water Resources Engineering Education. Int. J. Eng. Educ. 2019, 35, 1353-1365.

35. Salgado, T.; Martins, T.L.; Junqueira, M.B. Water: The experience of the Environmental Education programs promoted by the Municipal Department of Water and Sewer (DMAE) in the Municipality of Uberlandia. REMEA Rev. Electron. Mestr. Educ. Ambient. 2018, 1, 253-266. [CrossRef]

36. Mazas, B.; Gil-Quilez, M.J.; Martínez-Peña, B.; Hervas, A.; Muñoz, A. Early-childhood-education children think, act and talk about air and water behaviour. Enseñanza De Las Cienc. 2018, 36, 163-180. [CrossRef]

37. Demir, S.; Demir, N.M.; Karadeniz, A. An MS Excel tool for water distribution network design in environmental engineering education. Comput. Appl. Eng. Educ. 2018, 26, 203-214. [CrossRef]

38. Prieto, A.B.; Chrobak, R. Integration of ICT, metacognitive tools and research in science and environmental education. Case study: Availability of water, from basin of Patagonia northwestern and its relationship with solar activity. J. Educ. Teach. Train. 2013, 4, 133-141.

39. He, W.; Holton, A.; Farkas, G.; Warschauer, M. The effects of flipped instruction on out-of-class study time, exam performance, and student perceptions. Learn. Instr. 2016, 45, 61-71. [CrossRef]

40. López, J.; Pozo, S.; del Pino, M.J. Projection of the Flipped Learning Methodology in the Teaching Staff of Cross-Border Contexts. NAER 2019, 8, 184-200. [CrossRef]

41. Zainuddin, Z.; Habiburrahim, H.; Muluk, S.; Keumala, C.M. How do students become self-directed learners in the EFL flipped-class pedagogy? A study in higher education. Indones. J. Appl. Linguist. 2019, 8. [CrossRef]

42. Bergmann, J.; Sams, A. Flip Your Classroom: Reach Every Student in Every Class Every Day, 1st ed.; ISTE: Washington, DC, USA, 2012; pp. 34-40.

43. El Miedany, Y. Flipped learning. In The Flipped Classroom: Practice and Practices in Higher Education, 1st ed.; Reidsema, C., Kavanagh, L., Hadgraft, R., Smith, N., Eds.; Springer: Nueva York, NY, USA, 2019; Volume 1, pp. 285-303. [CrossRef]

44. Khadri, H.O. Flipped learning as a new educational paradigm: An analytical critical study. Eur. Sci. J. 2016, 12, 417-444. [CrossRef]

45. Zainuddin, Z.; Halili, S.H. Flipped classroom research and trends from different fields of study. Int. Rev. Res. Open Distrib. Learn. 2016, 17, 313-340. [CrossRef]

46. Abeysekera, L.; Dawson, P. Motivation and cognitive load in the flipped classroom: Definition, rationale and a call for research. High. Educ. Res. Dev. 2015, 34, 1-26. [CrossRef]

47. Long, T.; Cummins, J.; Waugh, M. Use of the flipped classroom instructional model in higher education: Instructors' perspectives. J. Comput. High. Educ. 2017, 29, 179-200. [CrossRef]

48. Schmidt, S.M.; Ralph, D.L. The Flipped Classroom: A Twist on Teaching. Contemp. Issues Educ. Res. 2016, 9 , 1-6. [CrossRef]

49. Bognar, B.; Sablić, M.; Škugor, A. Flipped learning and Online Discussion in Higher Education Teaching. In The Flipped Classroom: Practice and Practices in Higher Education, 1st ed.; Reidsema, C., Kavanagh, L., Hadgraft, R., Smith, N., Eds.; Springer: Nueva York, NY, USA, 2019; Volume 1, pp. 371-392. [CrossRef]

50. Long, T.; Logan, J.; Waugh, M. Students' perceptions of the value of using videos as a pre-class learning experience in the flipped classroom. TechTrends 2016, 60, 245-252. [CrossRef]

51. Tse, W.S.; Choi, L.Y.; Tang, W.S. Effects of video-based flipped class instruction on subject reading motivation. Br. J. Educ. Technol. 2019, 50, 385-398. [CrossRef]

52. Lee, J.; Park, T.; Davis, R.O. What affects learner engagement in flipped learning and what predicts its outcomes? Br. J. Educ. Technol. 2018, 1, 1-18. [CrossRef] 
53. Huang, B.; Foon, K.; Kwan, C. Investigating the effects of gamification-enhanced flipped learning on undergraduate students' behavioral and cognitive engagement. Inter. Learn. Environ. 2018, 1, 1-21. [CrossRef]

54. Castellanos, A.; Sánchez, C.; Calderero, J.F. Nuevos modelos tecnopedagógicos. Competencia digital de los alumnos universitarios. REDIE 2017, 19, 1-9. [CrossRef]

55. Hwang, G.J.; Lai, C.L.; Wang, S.Y. Seamless flipped learning: A mobile technology-enhanced flipped classroom with effective learning strategies. J. Comput. Educ. 2015, 2, 449-473. [CrossRef]

56. Chyr, W.L.; Shen, P.D.; Chiang, Y.C.; Lin, J.B.; Tsia, C.W. Exploring the effects of online academic help-seeking and flipped learning on improving students' learning. J. Educ. Technol. Soc. 2017, 20, 11-23. Available online: https://bit.ly/35RTgeS (accessed on 5 December 2019).

57. Báez, C.I.; Clunie, C.E. Una mirada a la Educación Ubicua. RIED 2019, 22, 325-344. [CrossRef]

58. Kwon, J.E.; Woo, H.R. The Impact of Flipped learning on Cooperative and Competitive Mindsets. Sustainability 2017, 10, 79. [CrossRef]

59. Cerezo, R.; Bernardo, A.; Esteban, M.; Sánchez, M.; Tuero, E. Programas para la promoción de la autorregulación en educación superior: Un estudio de la satisfacción diferencial entre metodología presencial y virtual. Eur. J. Educ. Psychol. 2015, 8, 30-36. Available online: https://bit.ly/2HLYrDa (accessed on 5 December 2019). [CrossRef]

60. Tourón, J.; Santiago, R. El modelo Flipped learning y el desarrollo del talento en la escuela. Rev. Educ. 2015, 1, 196-231. [CrossRef]

61. Hinojo, F.J.; Mingorance, Á.C.; Trujillo, J.M.; Aznar, I.; Cáceres, M.P. Incidence of the Flipped Classroom in the Physical Education Students' Academic Performance in University Contexts. Sustainability 2018, 10, 1334. [CrossRef]

62. Fisher, R.; Ross, B.; LaFerriere, R.; Maritz, A. Flipped learning, flipped satisfaction, getting the balance right. Teach. Learn. Inq. 2017, 5, 114-127. [CrossRef]

63. Karabulut, A.; Jaramillo, N.; Hassall, L. Flipping to engage students: Instructor perspectives on flipping large enrolment courses. Australas. J. Educ. Technol. 2018, 34, 123-137. [CrossRef]

64. Awidi, I.T.; Paynter, M. The impact of a flipped classroom approach on student learning experience. Comput. Educ. 2019, 128, 269-283. [CrossRef]

65. Nortvig, A.M.; Petersen, A.K.; Hattesen, S. A Literature Review of the Factors Influencing E-Learning and Blended Learning in Relation to Learning Outcome, Student Satisfaction and Engagement. Electron. J. ELearn. 2018, 16, 46-55. Available online: https://bit.ly/2W4iMHL (accessed on 5 December 2019).

66. Yoshida, H. Perceived usefulness of "flipped learning" on instructional design for elementary and secondary education: With focus on pre-service teacher education. Int. J. Inf. Educ. Technol. 2016, 6, 430-434. [CrossRef]

67. Huan, C. A Study on Digital Media Technology Courses Teaching Based on Flipped Classroom. Am. J. Educ. Res. 2016, 4, 264-267. [CrossRef]

68. Pozo, S.; López, J.; Moreno, A.J.; López, J.A. Impact of Educational Stage in the Application of Flipped Learning: A Contrasting Analysis with Traditional Teaching. Sustainability 2019, 11, 5968. [CrossRef]

69. Sola, T.; Aznar, I.; Romero, J.M.; Rodríguez, A.M. Eficacia del método flipped classroom en la universidad: Meta-análisis de la producción científica de impacto. REICE 2019, 17, 25-38. [CrossRef]

70. Thai, N.T.; De Wever, B.; Valcke, M. The impact of a flipped classroom design on learning performance in higher education: Looking for the best "blend" of lectures and guiding questions with feedback. Comput. Educ. 2017, 107, 113-126. [CrossRef]

71. Hinojo, F.J.; Aznar, I.; Romero, J.M.; Marín, J.A. Influencia del aula invertida en el rendimiento académico. Una revisión sistemática. Campus Virtuales 2019, 8, 9-18. Available online: https://bit.ly/2MP6Arz (accessed on 5 December 2019).

72. López, J.; Fuentes, A.; López, J.A.; Pozo, S. Formative Transcendence of Flipped Learning in Mathematics Students of Secondary Education. Mathematics 2019, 7, 1226. [CrossRef]

73. Hinojo, F.J.; López, J.; Fuentes, A.; Trujillo, J.M.; Pozo, S. Academic Effects of the Use of Flipped Learning in Physical Education. Int. J. Environ. Res. Public Health 2020, 17, 276. [CrossRef]

74. Larionova, V.; Brown, K.; Bystrova, T.; Sinitsyn, E. Russian perspectives of online learning technologies in higher education: An empirical study of a MOOC. Res. Compar. Int. Educ. 2018, 13, 70-91. [CrossRef]

75. Fernández, M.; Espada, M. Formación inicial y percepción del profesorado sobre los estilos de enseñanza en Educación Física. Retos 2017, 1, 69-75. 
76. Pérez, A. Uso de smartphones y redes sociales en alumnos/as de educación primaria. Prism. Soc. 2018, 1, 76-91.

77. Santiago, R.; Bergmann, J. Aprender al Revés, 1st ed.; Paidós Educación: Barcelona, Spain, 2018; pp. $133-142$.

78. Hernández, R.; Fernández, C.; Baptista, M.P. Metodología de la Investigación, 6th ed.; McGraw Hill: Madrid, Spain, 2014; pp. 129-168.

79. Rodríguez, N. Diseños experimentales en educación. REP 2011, 32, 147-158.

80. Chou, P.N.; Feng, S.T. Using a Tablet Computer Application to Advance High School Students' Laboratory Learning Experiences: A Focus on Electrical Engineering Education. Sustainability 2019, 11, 381. [CrossRef]

81. Yilmaz, A.; Soyer, F. Effect of Physical Education and Play Applications on School Social Behaviors of Mild-Level Intellectually Disabled Children. Educ. Sci. 2018, 8, 89. [CrossRef]

82. Amador, L.V.; Mateos, F.; Esteban, M. La educación como medio para la inclusión social entre culturas (los valores sociales de los jóvenes ceutís de cultura cristiana y musulmana). Pedagog. Soc. 2017, 1, 67-80.

83. Molina, P.J. Ceuta y su relación con las amenazas emergentes. Rev. De Pens. Estra. Y Seg. 2017, 2, 9-20.

84. Driscoll, T. Flipped Learning and Democratic Education. Ph.D. Thesis, Columbia University, New York, NY, USA, 2012.

85. Martín, D.; Sáenz, M.; Santiago, R.; Chocarro, E. Diseño de un instrumento para evaluación diagnóstica de la competencia digital docente: Formación flipped classroom. DIM 2016, 1, 1-15. Available online: https://bit.ly/2BlOqby (accessed on 5 December 2019).

86. Jöreskog, K.G. Analysis of Ordinal Variables 2: Cross-Sectional Data. In Text of the Workshop "Structural Equation Modelling with LISREL 8.51"; Friedrich-Schiller-Universität Jena: Jena, Germany, 2001; pp. 116-119.

(C) 2020 by the authors. Licensee MDPI, Basel, Switzerland. This article is an open access article distributed under the terms and conditions of the Creative Commons Attribution (CC BY) license (http://creativecommons.org/licenses/by/4.0/). 